\title{
THE MATHEMATICAL MODEL FOR THE CLTE OF SOLIDS STUDY USING THE STRUCTURAL UNITS METHOD
}

\section{МАТЕМАТИЧНА МОДЕЛЬ ДЛЯ ДОСЛІДЖЕННЯ ДИНАМІЧНОГО КОЕФІЦІНТА РОЗШИРЕННЯ МЕТАЛУ ЗА ДОПОМОГОЮ МЕТОДУ СТРУКТУРНИХ ОДИНИЦЬ}

\author{
Konstantin D. Evfimko \\ kostiantyn.yevfymko@nuos.edu.ua \\ ORCID: 0000-0002-1667-4777 \\ Natalia O. Shapoval \\ natalia.shapoval@nuos.edu.ua \\ ORCID: 0000-0002-5452-8148 \\ Sergiy S. Koval \\ sergiy.koval@nuos.edu.ua \\ ORCID: 0000-0002-3122-6024
}

\author{
К. Д. Свфимко, \\ ст. викладач \\ Н. О. Шаповал, \\ канд. техн. наук, доцент \\ С. С. Коваль, \\ канд. фіз.-мат. наук, доцент
}

Admiral Makarov National University of Shipbuilding, Mykolaiv

Національний університет кораблебудування імені адмірала Макарова, м. Миколаӥв

\begin{abstract}
The mathematical model and method for the thermal expansion coefficient of solids study using the structural units method is presented: theoretical and experimental approach based on the use of potentials of interatomic interaction and micro- and macrostructural data: atomic or molecular configuration of the structural unit, known parameters $(\mathrm{D}, \pm, \mathrm{r}$ ) of the modified Morse potential for metals (Al, $\mathrm{Cu}, \mathrm{Fe})$ and physical parameters of the whole object. This method involves the use of mathematical modeling in conjunction with experimental data: in the process of model equations computing using empirical data. Purposed method allows theoretical calculation of the microstructural dynamic linear (CLTE) and volumetric coefficient of thermal expansion taking into account the pro-cess time in the range between structural transitions in a wide temperature range with a known structural unit configuration, taking into account the energy characteristics of the polyatomic interaction of the microstructure. Calculations of the theoretical dynamic microstructural coefficient of linear expansion for $\mathrm{Al}, \mathrm{Cu}$ and $\mathrm{Fe}$ in a wide temperature range $(0-1500 \mathrm{C})$ according to known initial parameters of the interatomic potential are obtained and compared to experimental data of macrostructural coefficient of thermal expansion. The graphs of microstructural coefficient of thermal expansion values was obtained with the help of computer modeling compared to macrostructural coefficient of thermal expansion varies in range $5-12 \%$. Presented method can also be used in the case of alloys and solid solutions with a known microstructural configuration necessary for calculating the parameters of structural unit. The use of this model for calculating the parameters of anisotropic materials is possible only with regard to the use of the experimental structural unit density dependence on temperature, allows not only to obtain adequate results of calculations for the processes occurring in a particular material at the micro level, but also to understand the physical basis of these processes. Key words: structural unit; thermal expansion; SU method; CLTE; modified Morse potential.
\end{abstract}

Анотація. Наведено математичну модель і метод визначення коефіцієнта теплового розширення твердих тіл методом структурних одиниць: теоретико-експериментальний підхід, заснований на використанні потенціалів міжатомної взаємодії і мікро- та макроструктурних даних: атомної або молекулярної конфігурації структурної одиниці, відомих парамерів ( D , 土 , r ), модифікованого потенціалу Морзе для металів (Al, Cu, Fe), фізичних параметрів всього об'єкта. Даний метод передбачає використання математичного моделювання в сукупності з експериментальними даними: у процесі вирішення модельних рівнянь використовуються емпіричні дані. Запропонований метод дозволяє теоретично розрахувати мікроструктурні динамічні лінійні (CLTE) і об’ємні коефіцієнти теплового розширення з урахуванням часу процесу в діапазоні між структурними переходами в широкому діапазоні температур із відомою конфігурацією структурної одиниці з урахуванням енергетичних характеристик багатоатомної взаємодії мікроструктури. За допомогою комп'ютерних розрахунків отримано криві значень теоретичного динамічного мікроструктурного коефіцієнта лінійногорозширення для $\mathrm{Al}$, CuiFев широкому діапазонітемператур (0-1500 C)завідомимипочатковимипараметрами 
міжатомного потенціалу, порівняно їх із даними експериментального макроструктурного коефіцієнта теплового розширення. Розрахований мікроструктурний коефіцієнт теплового розширення порівняно з макроструктурним CLTE $€$ більш точним, ніж наявні теоретичні моделі та методи, та коливається в діапазоні 5-12\%. Представлений метод також може бути використаний щодо сплавів та твердих розчинів із відомою мікроструктурною конфігурацією, що необхідно для розрахунку параметрів структурної одиниці. Використання цієї моделі для розрахунку параметрів анізотропних матеріалів можливе лише з урахуванням використання експериментальної залежності густини структурної одиниці від температури, дозволяє не тільки отримати адекватні з погляду експерименту результати розрахунків для процесів у тому чи іншому матеріалі на мікрорівні, але й зрозуміти фізичні основи даних явищ.

Ключові слова: структурна одиниця; теплове розширення; метод структурних одиниць; коефіцієнт лінійного теплового розширення; модифікований потенціал Морзе.

\section{FORMULATION OF THE PROBLEM}

Studying the processes in crystalline materials in a wide range of temperatures, close to absolute zero and structural transitions, changes the state, in particular is a very non-trivial task, even with the current development of the measurement methodology. Theoretical studying heating or deformation processes` mechanical and thermal characteristics in microstructures, taking into account the speed of these changes is of practical interest nowadays.

\section{ANALYSIS OF RECENT RESEARCH AND PUBLICATIONS}

The method of structural units (SU) $[1 ; 2]$ presented by us in previous works is based on the following principles and assumptions: crystalline solids are composed of structural units, close to an absolute zero temperature $T_{0}=0 \mathrm{~K}$ these structural units volume is $V_{0}=r_{0}^{3}$, where $r_{0}$ - interatomic distance at $T_{0}=0 \mathrm{~K}$; the additivity principle is the correspondence of the physical properties of the structural unit to the physical properties of the macrostructure - the whole solid, consisting of these structural units; scaling - equations describing physical processes retain when all scales and time intervals change by the same; the existence of interatomic forces: attraction and repulsion, at a temperature $T_{0}=0 \mathrm{~K}:{F^{-}}_{T_{0}}=F^{+}{ }_{T_{0}}=0$; The SU method makes it possible theoretical calculation of mechanical and thermodynamic processes parameters occurring in cubic crystal system (cP (sc), cI (bcc), cF $(\mathrm{fcc}))$ in certain temperature ranges.

\section{PURPOSE OF THE STUDY}

The purpose of this work is to create a method that allows theoretical calculation of the dynamic linear (CLTE) and volumetric coefficient of thermal expansion taking into account the process time in the range between structural transitions in a wide temperature range, and this method allows to calculate the microstructural CLTE and volumetric coefficient of thermal expansion for both isotropic and anisotropic solids, with a known SU configuration, taking into account the energy characteristics of the polyatomic interaction of the microstructure.

\section{THE MAIN MATERIAL}

Generally, the CLTE of the cubic structure can be represented as:

$$
\alpha_{L}=\frac{1}{3 r^{3}}\left(\frac{d V}{d T}\right),
$$

where $r$ - the lattice parameter of the material.

As a potential describing the interaction of atoms in a structural unit (elementary structure) it is possible to use a modified Morse potential of the form:

$$
\Pi(r)=D\left(e^{-2 \pm r}-2 e^{ - \pm r}\right),
$$

where $D-$ dissociation energy, the well depth, \pm - substance dependent constant that controls the width of the potential.

We assume that the relative values of the energy of a structural unit at each point of the volume is a superposition of all the potentials of the atoms in the structural unit, or a cluster consisting of several structural units. In more detail, this technique is described in [3], here we present only the final equations for calculating the relative integral energy density of a structural unit with regard to its volume distribution.

$$
\varepsilon=\sum_{\gamma=1}^{N} \Pi_{\gamma}
$$

where $\gamma=1,2 \ldots N$ - the number of particles (atoms) of SU or microstructure taken into account (fig. 1)

Accordingly, using given value of the elementary step of deformation ' $r\left({ }^{\prime} \tau\right)$ and the time of the elementary deformation event, it is possible to calculate the relative change in energy:

$$
\delta \varepsilon\left({ }^{\prime} r,^{\prime} \tau\right)=\sum_{\gamma=1}^{N} \delta \Pi\left({ }^{\prime} r,^{\prime} \tau\right)_{\gamma} .
$$

Consequently, the increment of the thermodynamic temperature $\delta T$ corresponding to the elementary act of thermal expansion ' $r\left({ }^{\prime} \tau\right)$ of the isotropic structural unit is:

$$
\delta T\left({ }^{\prime} r,^{\prime} \tau\right)=\frac{1}{k_{b}} \sum_{\gamma=1}^{N} D\left(e^{\left.-2 \pm^{\prime} r^{\prime} \tau\right)}-2 e^{- \pm^{\prime} r\left({ }^{\prime} \tau\right)}\right)_{\gamma} .
$$

This allows to calculate the sample temperature heating dependence on time (fig. 2), which makes it possible to calculate the dynamic microstructural coefficient of linear thermal expansion.

From (2-5), we obtain the expression for the microstructural coefficients of linear and volumetric thermal expansion, respectively: 

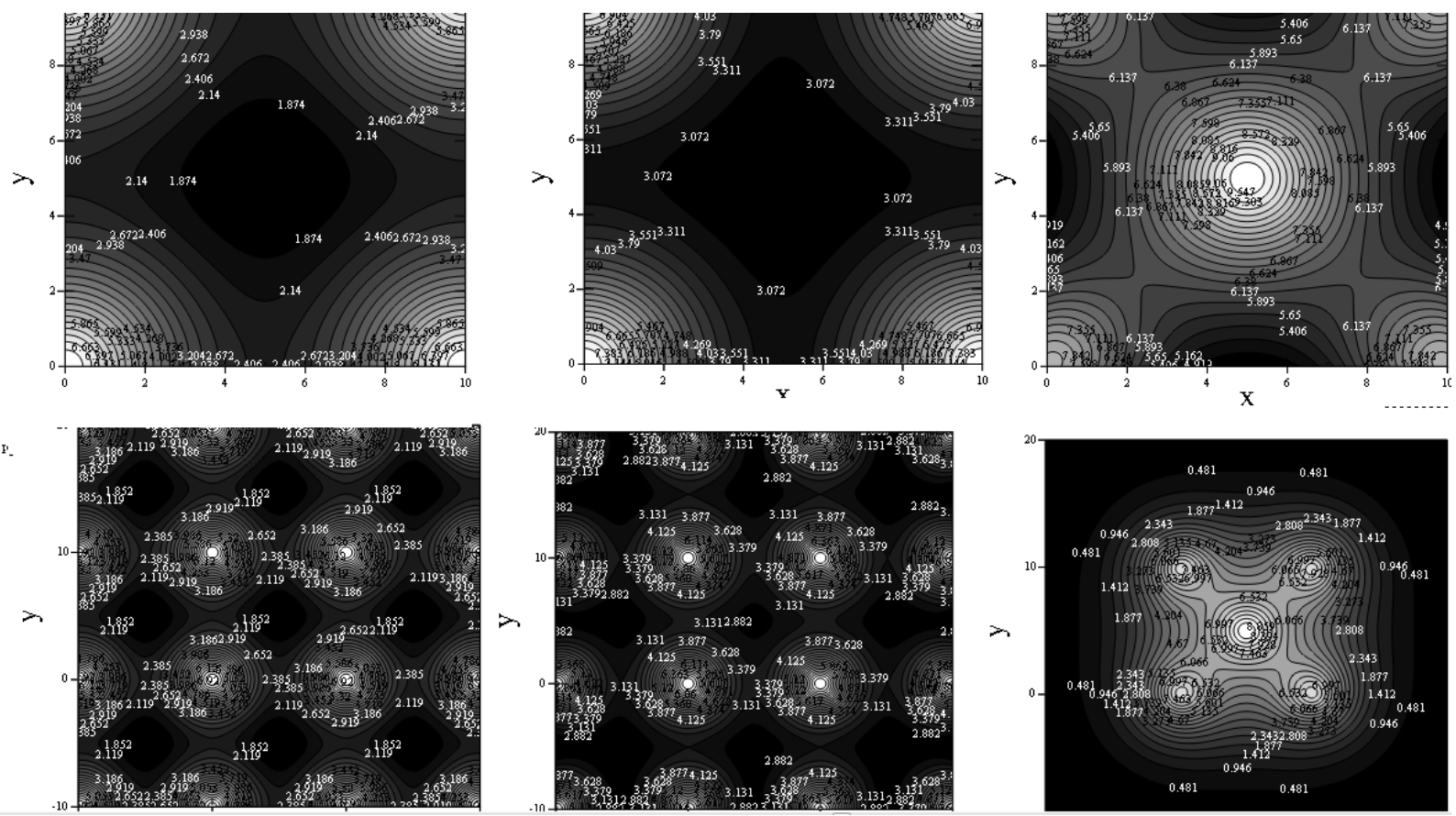

Fig. 1. The distribution of the relative integral energy density on the edge of a cubic, bcc and fcc structure, and on the edge of a microstructure (cluster) consisting of 4 cubic and bec structural units

$$
\alpha_{L}=\frac{r^{\prime} k_{b}}{3 r^{3} \sum_{\gamma=1}^{N} \delta D\left(e^{-2 t^{\prime} r}-2 e^{- \pm^{\prime} r}\right)_{\gamma}},
$$

$$
\beta=\frac{r^{\prime} k_{b}}{r^{3} \sum_{\gamma=1}^{N} \delta D\left(e^{-2 \pm^{\prime} r}-2 e^{- \pm^{\prime} r}\right)_{\gamma}} .
$$

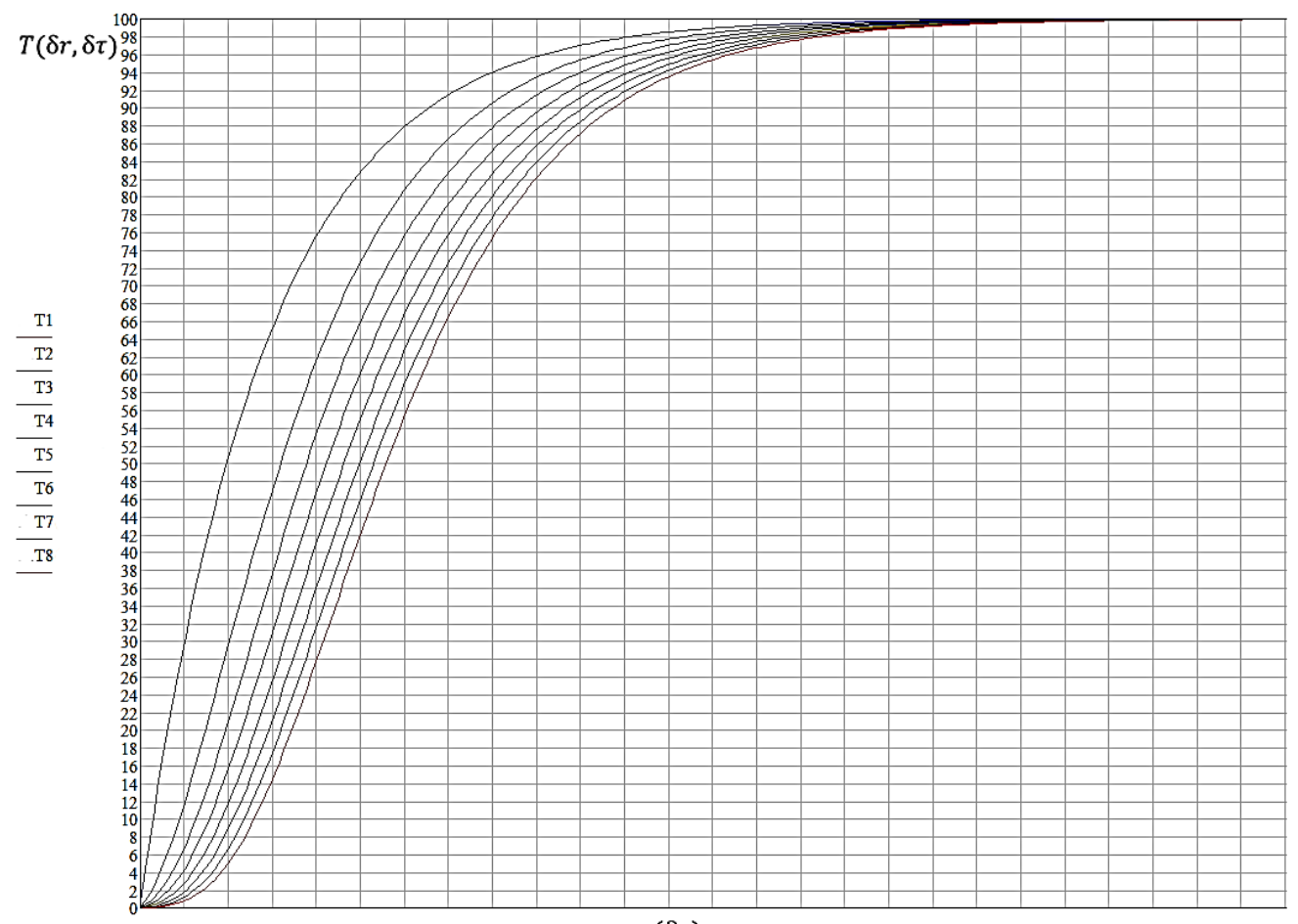

$\tau(\delta r) \quad 0-40010 \mathrm{E}-18 \mathrm{c}$

Fig. 2. Temperature dependence of the heating time for 8 structural units with a difference in temperature of the sample and the external environment of $100 \mathrm{~K}$ 


\section{DISCUSSION OF THE OBTAINED RESULTS}

As a result of the calculation using this method, the values of the dynamic coefficient of linear expansion for pure metals were obtained in a wide temperature range with known initial parameters of the modified Morse potential. Table 1 presents the known parameters of the modified potential that were used in the calculations, the results of the computational experiment $\alpha_{L}$ and the comparison with known experimental data $\alpha_{L E X P}$
[7]. Figures 3-4 presents the dependences of the calculated microstructural and experimental macrostructural linear expansion coefficient (CLTE) of $\mathrm{Al}, \mathrm{Cu}, \mathrm{Fe}$ in the temperature range $0-1500 \mathrm{C}$.

Since the parameters of the interatomic Morse potential are known for a wide range of solids, the proposed method for calculating the dynamic coefficient of thermal expansion, being rather difficult for analytical calculation, makes it possible accurate theoretical calculation of the lin-

Table 1. Parameters of the modified Morse potential (D, $\alpha, r)$, calculation results of microstructural $\pm_{L}$ in comparison with knows experimental data of $\pm_{\mathbf{L E X P}}$

\begin{tabular}{|c|c|c|c|c|c|c|}
\hline$\Pi$ parameters & \multicolumn{2}{|c|}{$\mathrm{Al}$} & \multicolumn{2}{|c|}{$\mathrm{Cu}$} & \multicolumn{2}{|c|}{$\mathrm{Fe}$} \\
\hline$D, \mathrm{eV}$ & \multicolumn{2}{|c|}{0,2703} & \multicolumn{2}{|c|}{0,3429} & \multicolumn{2}{|c|}{0,4174} \\
\hline$\alpha$ & \multicolumn{2}{|c|}{1,1646} & \multicolumn{2}{|c|}{1,3588} & \multicolumn{2}{|c|}{1,3885} \\
\hline $\mathrm{r}$ & \multicolumn{2}{|c|}{3,253} & \multicolumn{2}{|c|}{2,866} & \multicolumn{2}{|c|}{2,845} \\
\hline$T, C$ & $\begin{array}{c}\alpha_{L} \\
10^{-6} \mathrm{~K}^{-1}\end{array}$ & $\begin{array}{c}\alpha_{L E X P} \\
10^{-6} \mathrm{~K}^{-1}\end{array}$ & $\begin{array}{c}\alpha_{L} \\
10^{-6} \mathrm{~K}^{-1}\end{array}$ & $\begin{array}{c}\alpha_{L E X P} \\
10^{-6} \mathrm{~K}^{-1}\end{array}$ & $\begin{array}{c}\alpha_{L} \\
10^{-6} \mathrm{~K}^{-1}\end{array}$ & $\begin{array}{c}\alpha_{L E X P} \\
10^{-6} \mathrm{~K}^{-1}\end{array}$ \\
\hline 0 & 20,25 & 22,8 & 14,02 & 16,70 & 10,57 & 11,30 \\
\hline 100 & 27,23 & 23,7 & 18,05 & 17,06 & 14,53 & 12,15 \\
\hline 200 & 28,23 & 24,5 & 18,83 & 17,42 & 14,81 & 12,70 \\
\hline 300 & 28,55 & 25,4 & 19,05 & - & 15,13 & - \\
\hline 400 & 29,10 & 26,2 & 19,45 & 18,14 & 15,45 & 13,80 \\
\hline 500 & 29,66 & 27,1 & 19,63 & - & 15,51 & - \\
\hline 600 & 30,27 & 27,9 & 20,05 & 18,86 & 15,86 & 14,50 \\
\hline 700 & 24,06 & - & 20,36 & - & 16,05 & - \\
\hline 800 & 18,52 & - & 20,55 & 19,58 & 16,19 & 14,80 \\
\hline 900 & 14,58 & - & 20,86 & - & 16,35 & - \\
\hline 1000 & 11,51 & - & 20,15 & 20,30 & 16,56 & - \\
\hline
\end{tabular}

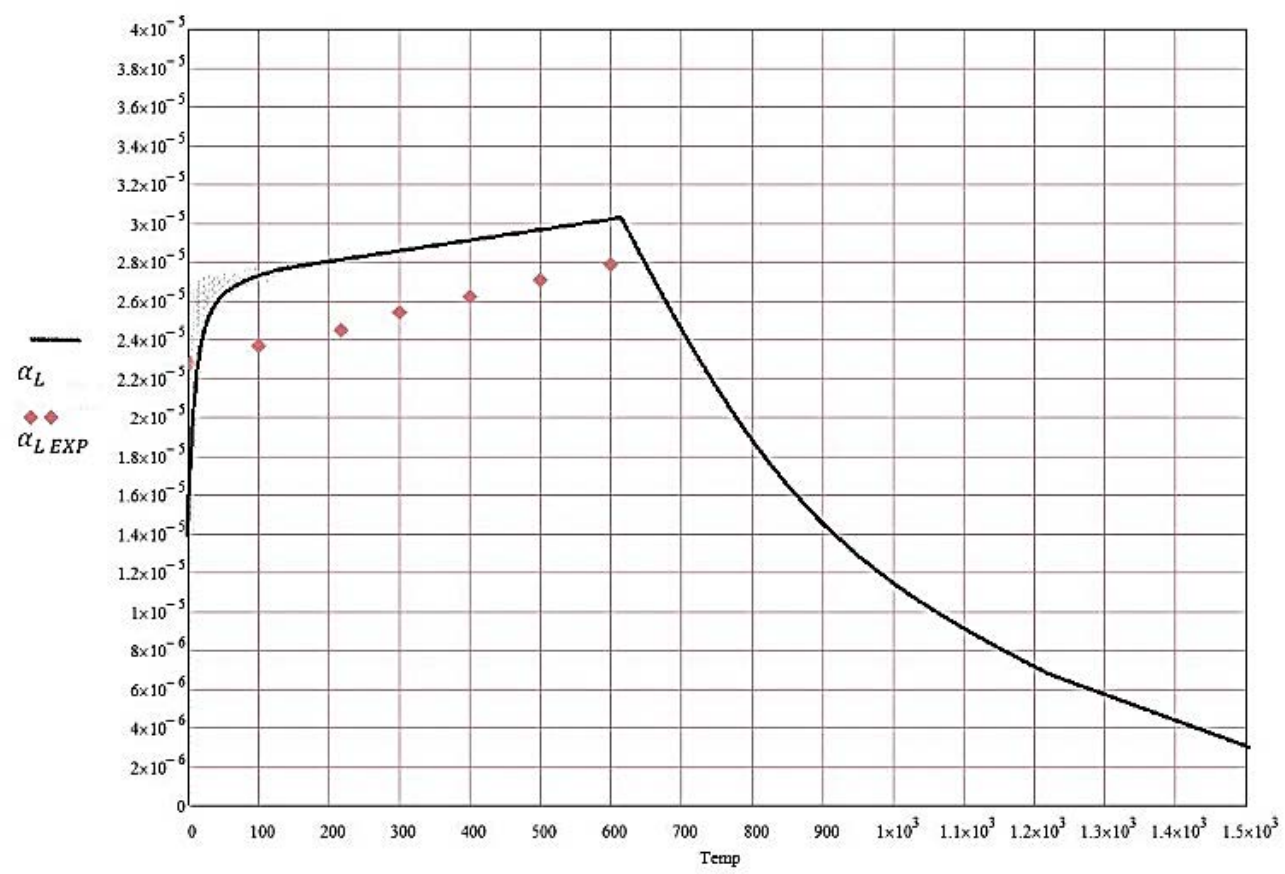

Fig. 3. Calculated dynamic microstructural CLTE $\pm_{L}$ and its known experimental values $\pm_{L E X P}$ in the temperature range $0-1500 \mathrm{C}$ for $\mathrm{Al}$ 
ear coefficient of thermal expansion, and in the case of isotropy, the volumetric coefficient of thermal expansion using (7). It can also be used in the case of alloys and solid solutions with a known microstructural configuration necessary for calculating the parameters of SU.

\section{CONCLUSIONS}

Analysis of the calculated results allows us to conclude some discrepancy of calculated micostructural
CLTE with the known experimental data of macrostructural CLTE (about 5-12\%), this is due to the need for some correction of the interatomic potential parameters and imperfect empirical measurement techniques, which can also have significant error. The presented method allows to calculate the coefficient of temperature expansion in the temperature range from $0 \mathrm{C}$ to the melting point in the case of $\mathrm{Cu}$ and $\mathrm{Al}$, however, in the case

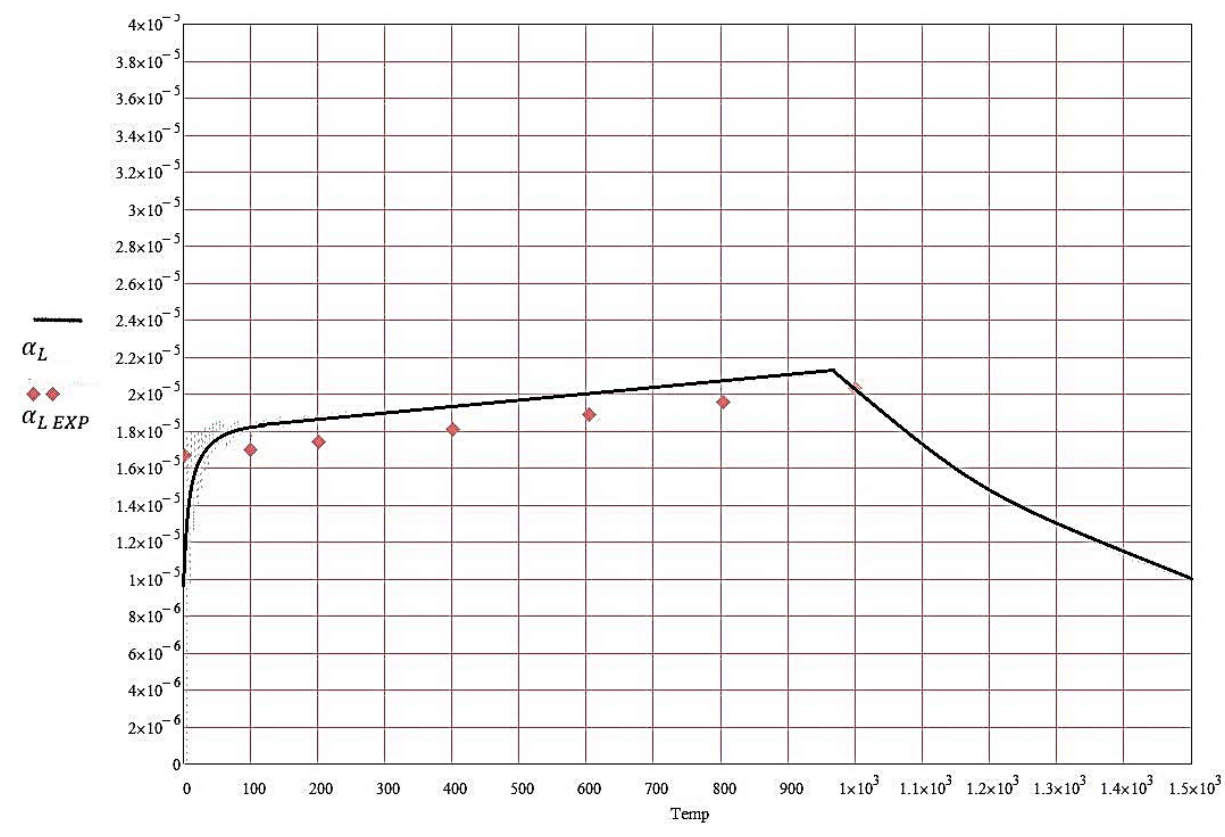

Fig. 4. Calculated dynamic microstructural CLTE $\pm_{L}$ and its known experimental values $\pm_{L E X P}$ in the temperature range $0-1500 \mathrm{C}$ for $\mathrm{Cu}$

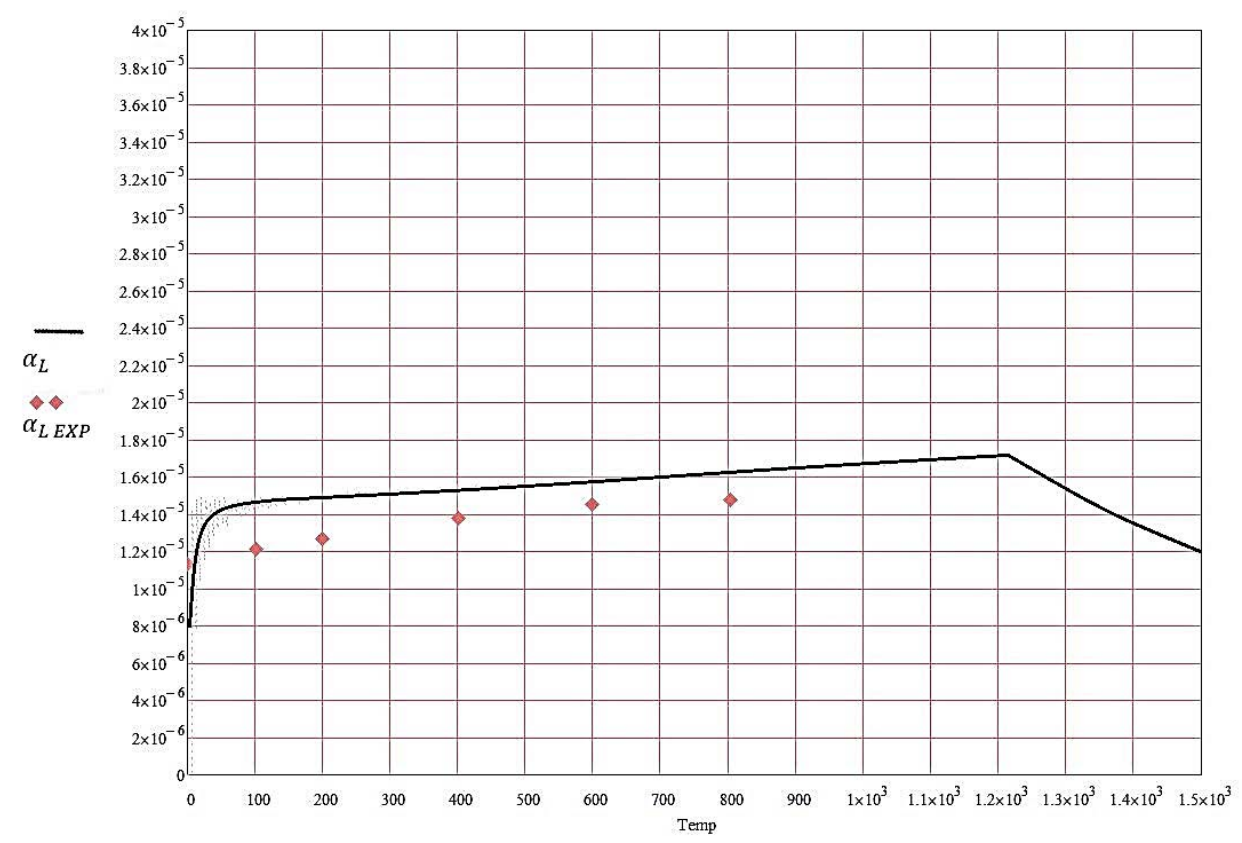

Fig. 5. Calculated dynamic microstructural CLTE $\pm_{L}$ and its known experimental values $\pm_{L E X P}$ in the temperature range $0-1500 \mathrm{C}$ for $\mathrm{Fe}$ 
of Fe, the model can be correctly used only up to $906 \mathrm{C}$, since it needs to be modernized, by taking into account the adjustment from bcc to fcc. The use of this model for calculating the parameters of anisotropic materials is possible only with regard to the use of the experimental SU density dependence on temperature.

\section{REFERENCES}

[1] Mochalov, A. A., Gaisha, A. A., Evfimko, K. D. (2009). Dinamika deformatsii strukturnoy edinitsy tverdogo tela ot vneshnego vozdeystviya. J. Nano- Electron. Phys. T.1, № 1. - pp.70-79. [in Russian]

[2] Mochalov, A. A., Gaisha, A. A., Evfimko, K. D. (2014). Issledovaniya temperaturnykh kharakteristik tverdogo tela na mikrourovne s pomoshchyu metoda strukturnykh edinits. J. Nano-Electron. Phys. T. 6 № 4. - p. 04040 [in Russian]

[3] Evfimko, K. D., Mochalov O. O., Shapoval, N. O., Koval, S. S. (2018). Rozrakhunok rozpodilu gustini mizhatomnogo potyentsialu u strukturniy odinitsi ryechovini. Matematichne modelyuvannya. № 1, 38 pp. 160-164. DOI: 10.31319/25198106.1(38)2018.129530 [in Ukrainian]

[4] Mochalov, A. A., Evfimko, K. D. (2008). Issledovanie vliyaniya vysokogo davleniya na makroskopicheskie parametry metalla. Visnik SumDU. № 1, pp. 156-160. [in Russian]

[5] Mochalov, A. A., Evfimko, K. D., Gaisha, A. A. (2011). Fenomenologichna model tverdogo tila z urakhuvannyam kinetiki deformatsiï. Matematichne modelyuvannya. № 2, p. 25 [in Ukrainian]

[6] Kryvtsov, A. M. (2007). Deformirovanie i razrushenie tverdykh tel s mikrostrukturoy. Moscow: Fizmatlit, 304 p. [in Russian]

[7] Kaye, G. W. C., Laby, T. H. (1993). Tables of physical and chemical constants, Longman, London, UK, 15th edition.

\section{BIBLIOGRAPHY}

[1] Мочалов А. А., Гайша А. А., Евфимко К. Д. Динамика деформации структурной единицы твердого тела от внешнего воздействия. Журнал нано- и электронной физики. 2009. Т. 1. № 1. С. 70-79.

[2] Мочалов А. А., Гайша А. А., Евфимко К. Д. Исследования температурных характеристик твердого тела на микроуровне с помощью метода структурных единиц. Журнал нано- и электронной физики. 2014. Т. 6 № 4. С. 04040.

[3] Розрахунок розподілу густини міжатомного потенціалу у структурній одиниці речовини / К. Д. Свфимко та ін. Математичне моделювання. 2018. № 1, 38. С. 160-164.

[4] Мочалов А. А., Евфимко К. Д. Исследование влияния высокого давления на макроскопические параметры металла. Вісник Сумського державного університету. 2008. № 1. С. 156-160.

[5] Мочалов О. О., Євфимко К. Д., Гайша О. О. Феноменологічна модель твердого тіла з урахуванням кінетики деформації. Математичне моделювання. 2011. № 2. С. 25.

[6] Кривцов А. М. Деформирование и разрушение твердых тел с микроструктурой. Москва : Физматлит, 2007. 304 с.

[7] Kaye G. W. C., Laby T. H. Tables of physical and chemical constants. 15'th edition. London, UK : Longman, 1993.

( С К. Д. Євфимко, Н. О. Шаповал, С. С. Коваль Дата надходження статті до редакції: 16.10 .2020 Дата затвердження статті до друку: 23.10.2020 